\title{
Article \\ Impact of Sainfoin (Onobrychis viciifolia) Pellets on Parasitological Status, Antibody Responses, and Antioxidant Parameters in Lambs Infected with Haemonchus contortus
}

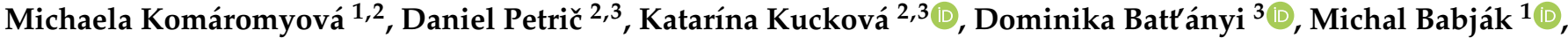 \\ Michaela Urda Dolinská ${ }^{1}{ }^{\circledR}$, Alžbeta Königová ${ }^{1}{ }^{\circledR}$, Daniel Barčák ${ }^{1}{ }^{1}$, Emília Dvorožňáková ${ }^{1}$, Klaudia Čobanová ${ }^{3}$, \\ Zora Váradyová ${ }^{3, *}$ (1) and Marián Várady ${ }^{1, * \mathbb{D}}$
}

check for updates

Citation: Komáromyová, M.; Petrič, D.; Kucková, K.; Batt'ányi, D.; Babják, M.; Dolinská, M.U.; Königová, A.; Barčák, D.; Dvorožňáková, E.; Čobanová, K.; et al. Impact of Sainfoin (Onobrychis viciifolia) Pellets on Parasitological Status, Antibody Responses, and Antioxidant Parameters in Lambs Infected with Haemonchus contortus. Pathogens 2022, 11, 301. https://doi.org/10.3390/ pathogens 11030301

Academic Editors: Jackson Victor de Araújo and Lawrence S. Young

Received: 14 January 2022

Accepted: 24 February 2022

Published: 27 February 2022

Publisher's Note: MDPI stays neutral with regard to jurisdictional claims in published maps and institutional affiliations.

Copyright: (C) 2022 by the authors. Licensee MDPI, Basel, Switzerland. This article is an open access article distributed under the terms and conditions of the Creative Commons Attribution (CC BY) license (https:// creativecommons.org/licenses/by/ $4.0 /)$.
1 Institute of Parasitology, Slovak Academy of Sciences, Hlinkova 3, 04001 Košice, Slovakia; komaromyova@saske.sk (M.K.); babjak@saske.sk (M.B.); dolinska@saske.sk (M.U.D.); konig@saske.sk (A.K.); barcak@saske.sk (D.B.); dvoroz@saske.sk (E.D.)

2 University of Veterinary Medicine and Pharmacy in Košice, Komenského 73, 04181 Košice, Slovakia; petric@saske.sk (D.P.); kuckova@saske.sk (K.K.)

3 Centre of Biosciences of Slovak Academy of Sciences, Institute of Animal Physiology, Šoltésovej 4-6, 04001 Košice, Slovakia; mravcakova@saske.sk (D.B.); boldik@saske.sk (K.Č.)

* Correspondence: varadyz@saske.sk (Z.V.); varady@saske.sk (M.V.); Tel.: +421-55-792-2972 (Z.V.); +421-55-633-1411-13 (M.V.)

\begin{abstract}
Our study analyzed the parasitological status, antibody responses, and antioxidant parameters of lambs experimentally infected with a gastrointestinal nematode during the consumption of sainfoin pellets (SFPs) for $14 \mathrm{~d}$. Twenty-four lambs infected with Haemonchus contortus were separated into two groups: untreated animals (control) and animals treated with SFPs (600 g dry matter/d). SFP treatment began on day (D) 30 post-infection. The number of eggs per gram (EPG) of feces was quantified on D18, D23, D26, D30, D33, D37, D40, and D44. The mean reductions in EPG on D40 and D44 were 33.6 and $36.7 \%$, respectively. The number of abomasal worms was lower for the SFP than the control group $(p<0.05)$. SFP treatment did not significantly affect either the total or the local antibody response $(p>0.05)$. The blood activity of glutathione peroxidase was affected by the treatment $(p<0.022)$. Adult worms were selected for scanning electron microscopy after necropsy, but surface structures of adult $H$. contortus females did not differ between the groups. The treatment of lambs with SFPs directly affected the dynamics of infection, probably indirectly by mobilizing the antioxidant defensive system and antibody response thus improving animal resistance.
\end{abstract}

Keywords: antibody response; antioxidant status; abomasal adult worms; egg hatch test; fecal egg counts; scanning electron microscopy

\section{Introduction}

The demand for animal products is growing worldwide with the increase of the human population. The intensification of livestock production leads to environmental burdens such as increased use of chemicals and drugs to eliminate the transmission of etiological agents and the pressure on systems of livestock production to ensure feed of sufficient quality [1]. Chemoprophylaxis is currently the most effective method of preventing severe losses in livestock caused by gastrointestinal nematodes (GINs). However, without consideration of maintaining a certain refugium, these practices can be considered inappropriate and unsustainable in the long term, because resistance to any new drug may develop within 10 years [2]. Among the GINs of small ruminants, the highly pathogenic Haemonchus contortus represents a major threat in animal husbandry. H. contortus is a common cause of production losses and even deaths in livestock due to its blood-sucking behavior and rapid reproduction [3]. Parasitism increases the demands on the resources of proteins and calories from the repair of damaged tissues and the production of immune 
cells and mediators of the immune response $[4,5]$. The nutritional status of the host has been considered an important factor influencing the pathogenesis of parasitic diseases and the relationship between the host and parasite [6]. Controlling the intensity of parasitic infection can improve nutritional deficits and the overall health of the animal [7].

The antiparasitic activity of polyphenols not only directly affects parasites [7] but also indirectly modulates the immune response [8]. Oxidative stress is known to occur when reactive oxygen species or free radicals exceed the detoxification capacity of antioxidants [9]. GIN infections may induce the production of reactive oxygen species, which may damage the parasites but generate oxidative stress by the formation of reactive oxygen molecules (e.g. superoxide radicals, hydroxyl radicals, and hydrogen peroxide) [10]. Feed supplementation with medicinal herbs containing bioactive compounds may attenuate the adverse effects of parasite infection by stimulating endogenous antioxidant defense systems and helping trigger local immune responses in the abomasal mucosa of small ruminants [11,12]. Polyphenols are the most common antioxidants known for their immunomodulatory and anti-inflammatory activities [13]. One possible way to control and reduce infection caused by GINs is the use of tanniferous forages containing condensed tannins (CTs) with direct anthelmintic effects on GINs, which can lead to a substantial decrease in the excretion of nematode eggs and reduce the contamination of pastures [14]. Electron microscopy has found that the direct anthelmintic effects of CTs can damage the cuticle and digestive tissues of larval or adult parasites [15]. The legume sainfoin, Onobrychis viciifolia, has a high content of CTs, especially proanthocyanidins, and its consumption disturbs different life stages of parasite life cycles $[16,17]$. The benefits of sainfoin use also include a reduced requirement for chemical fertilizers because of its biological fixation of nitrogen, high palatability for ruminants, feeding value, reduction of ruminal methane emission, anti-bloating effects, and nitrogen excretion in urine and feces [8].

The process of pelleting sainfoin (i.e. high temperature and pressure) does not affect the polyphenolic bioactivities linked to antioxidative properties [18], so we hypothesized that sainfoin pellets (SFPs) may also contribute to changing the course of infection caused by $H$. contortus in lambs by lowering fecal egg counts (FEC) and the number of adult worms in the abomasum and by improving the immune response and antioxidant status. Our goals were therefore to investigate the effect of SFPs on the parasitological status, immune response, and antioxidant parameters of lambs experimentally infected with $\mathrm{H}$. contortus.

\section{Results}

\subsection{Fecal Egg Count (FEC) and Weight Gains}

Lamb total body weight (BW) did not differ significantly between groups, but liveweight gain (LWG) was significantly lower $(p<0.05)$ in the control than in the SFP treated group. Changes in BW during the experimental period and differences in LWG at the end of the experiment are shown in Figure 1.

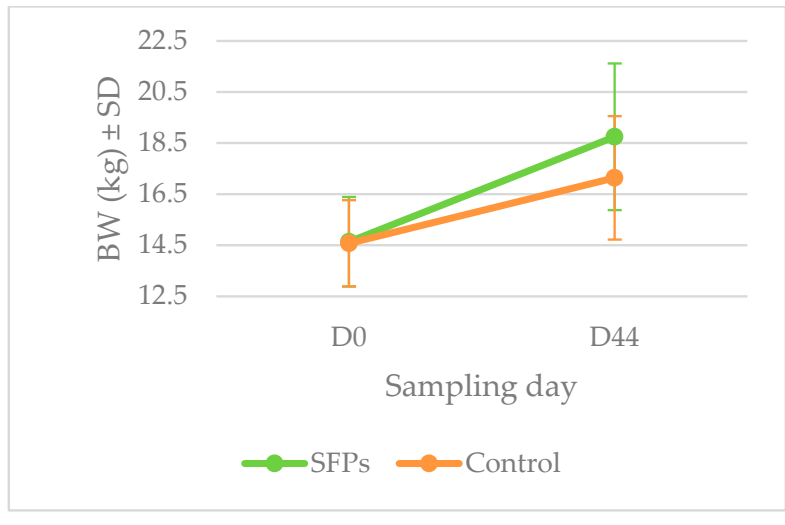

(a)

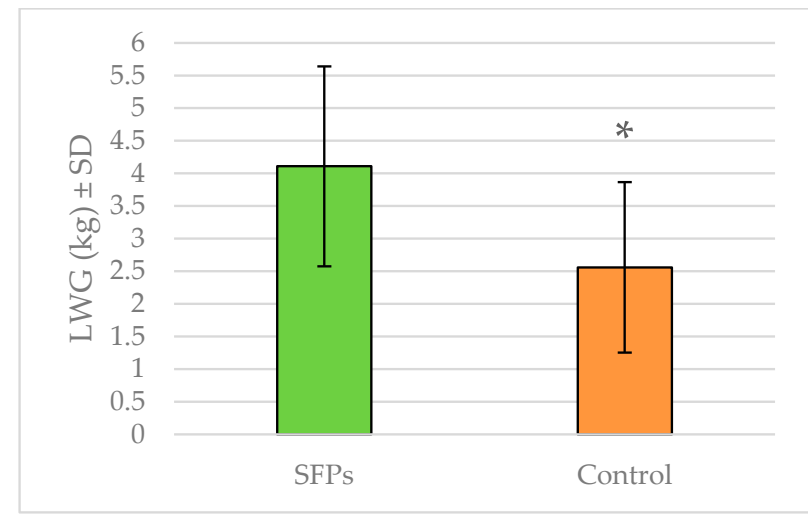

(b)

Figure 1. (a) Mean body weight (BW) and (b) mean live-weight gain (LWG) $\left(^{*}, p<0.05\right)$. 
Reduction in egg shedding $(13.7 \%)$ in the SFP group was first noticeable on day 37 (D37). A fecal egg count reduction test (FECRT) confirmed reductions of 33.6 and $36.7 \%$ $(p<0.05)$ on D40 and D44, respectively, in the SFP versus the control group. (Figure 2a). The number of abomasal worms after the necropsy was $30.6 \%$ lower in the SFP versus the control group ( $p<0.05$, Figure $2 b$ ). Female fecundity (per worm) did not differ significantly between the groups.

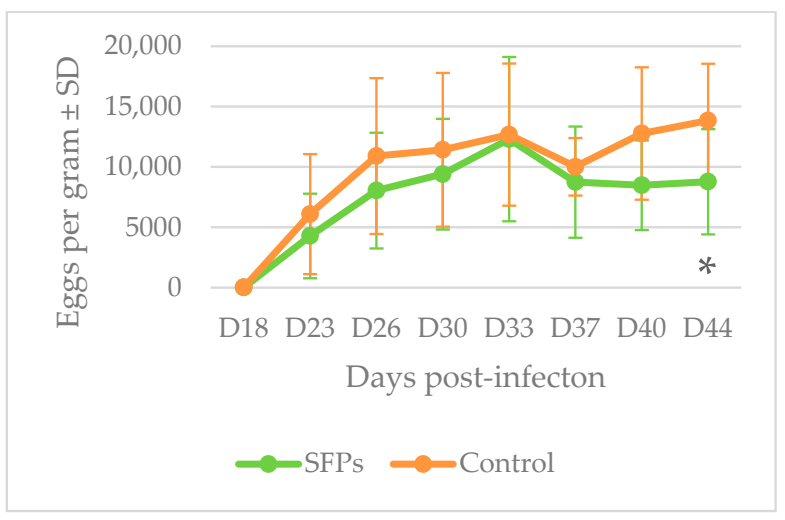

(a)

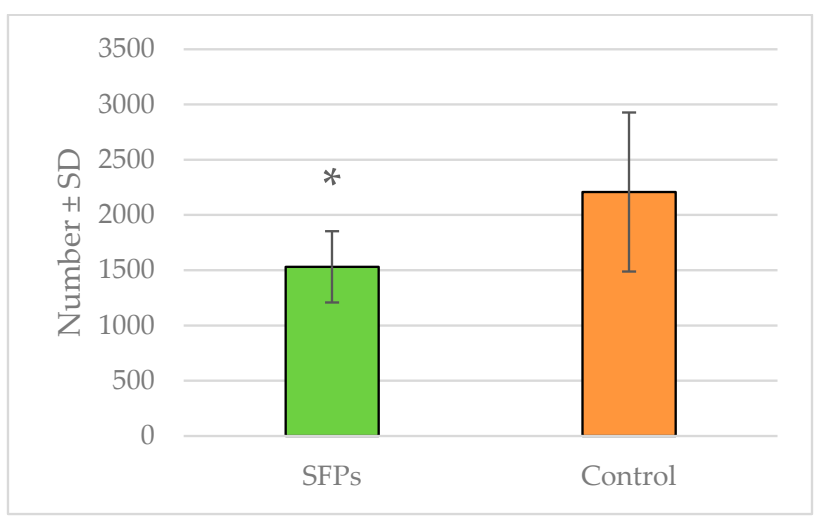

(b)

Figure 2. (a) Mean fecal egg counts for the groups of lambs infected with Haemonchus contortus and treated or not with SFPs $\left({ }^{*}, p<0.05\right)$. (b) Mean number of $H$. contortus worms in the abomasum at the end of the experiment $\left({ }^{*}, p<0.05\right)$.

\subsection{Egg Hatch Test (EHT)}

The aqueous extracts of the SFPs had a significant ovicidal effect on $H$. contortus, with mean $\mathrm{ED}_{50}$ and $\mathrm{ED}_{99}$ of 4.67 and $25.33 \mathrm{mg} / \mathrm{mL}$, respectively (Table 1). Each concentration of the SFP extract tested affected the proportion of hatched eggs $(p<0.001)$.

Table 1. Egg hatching and ovicidal activity of tested concentrations of SFPs extract in an EHT.

\begin{tabular}{cccc}
\hline Concentration $(\mathbf{m g} / \mathbf{m L})$ & Hatching $\mathbf{( \% )}$ & Ovicidal Effect $(\%)$ & $p$ \\
\hline 50 & $5 \pm 7.42$ & 95 & $<0.001$ \\
25 & $4 \pm 6.33$ & 96 & $<0.001$ \\
12.5 & $11 \pm 14.47$ & 89 & $<0.001$ \\
6.25 & $26 \pm 28.74$ & 74 & $<0.001$ \\
3.125 & $76 \pm 12.25$ & 24 & $<0.001$ \\
1.563 & $88 \pm 3.71$ & 12 & $<0.001$ \\
0 & $98 \pm 1.095$ & - & - \\
\hline
\end{tabular}

Mean egg hatching \pm SD $(\mathrm{n}=6)$.

\subsection{Antibody Responses}

The treatment did not significantly affect either the total (Table 2) or local (Table 3) antibody response of the treated animals $(p>0.05)$. Mean serum IgA concentrations and eosinophil peroxidase (EPx) increased over time ( $p<0.035$ and $p<0.001$, respectively), both peaking in both groups on D44 (Table 2).

Table 2. Total antibody response in the blood serum of infected lambs treated or not with SFPs.

\begin{tabular}{cccccccc}
\hline & Day & SFPs & Control & SD & & \multicolumn{2}{c}{$p$} \\
\cline { 5 - 8 } & & & & Treatment (T) & Time & T $\times$ Time \\
\hline \multirow{2}{*}{ IgG (OD) } & 23 & 0.357 & 0.361 & 0.0773 & & & 0.837 \\
& 30 & 0.397 & 0.374 & 0.1512 & 0.611 & 0.987 \\
\hline
\end{tabular}


Table 2. Cont.

\begin{tabular}{|c|c|c|c|c|c|c|c|}
\hline & \multirow{2}{*}{ Day } & \multirow{2}{*}{ SFPs } & \multirow{2}{*}{ Control } & \multirow{2}{*}{ SD } & \multicolumn{3}{|c|}{$p$} \\
\hline & & & & & Treatment (T) & Time & $\mathbf{T} \times$ Time \\
\hline \multirow{4}{*}{$\operatorname{IgA}(\mathrm{OD})$} & 23 & 0.405 & 0.401 & 0.0771 & \multirow{4}{*}{0.475} & \multirow{4}{*}{0.035} & \multirow{4}{*}{0.704} \\
\hline & 30 & 0.398 & 0.411 & 0.0651 & & & \\
\hline & 37 & 0.417 & 0.376 & 0.0751 & & & \\
\hline & 44 & 0.467 & 0.451 & 0.0580 & & & \\
\hline \multirow{4}{*}{$\operatorname{IgM}(\mathrm{OD})$} & 23 & 0.458 & 0.509 & 0.1048 & \multirow{4}{*}{0.453} & \multirow{4}{*}{0.175} & \multirow{4}{*}{0.821} \\
\hline & 30 & 0.479 & 0.479 & 0.1265 & & & \\
\hline & 37 & 0.489 & 0.535 & 0.1243 & & & \\
\hline & 44 & 0.566 & 0.555 & 0.1169 & & & \\
\hline \multirow{4}{*}{$\operatorname{EPx}(\mathrm{ng} / \mathrm{mL})$} & 23 & 22.7 & 18.2 & 13.70 & \multirow{4}{*}{0.509} & \multirow{4}{*}{0.001} & \multirow{4}{*}{0.814} \\
\hline & 30 & 28.6 & 25.3 & 15.76 & & & \\
\hline & 37 & 44.3 & 37.0 & 20.29 & & & \\
\hline & 44 & 47.6 & 51.5 & 16.02 & & & \\
\hline
\end{tabular}

IgG, immunoglobulin G; IgA, immunoglobulin A; IgM, immunoglobulin M; OD, optical density; EPx, eosinophil peroxidase; SD, standard deviation.

Table 3. Local antibody response in the abomasal mucus of lambs treated or not with SFPs.

\begin{tabular}{ccccc}
\hline & Day & SFP & Control & $p$ \\
\hline $\operatorname{IgA}(\mathrm{OD})$ & 44 & $0.401 \pm 0.0928$ & $0.441 \pm 0.0916$ & 0.280 \\
\hline OD, optical density. & & &
\end{tabular}

\subsection{Antioxidant Status}

Time and the interaction between treatment and time affected total antioxidant capacity (TAC, $p<0.004$ ) (Table 4), and treatment and time affected glutathione peroxidase (GPx) activity ( $p<0.022$ and $p<0.001$, respectively). GPx activity from D30 to D44 was higher for the control than the SFP group. The serum malondialdehyde (MDA) concentration was significantly influenced by time in both groups $(p<0.001)$.

Table 4. Antioxidant status in blood serum of infected lambs treated or not with SFPs.

\begin{tabular}{|c|c|c|c|c|c|c|c|}
\hline & \multirow{2}{*}{ Day } & \multirow{2}{*}{ SFPs } & \multirow{2}{*}{ Control } & \multirow{2}{*}{ SD } & \multicolumn{3}{|c|}{$p$} \\
\hline & & & & & Treatment $(\mathrm{T})$ & Time & $\mathbf{T} \times$ Time \\
\hline \multirow{5}{*}{ TAC (mmol/L) } & 0 & 0.578 & 0.527 & 0.062 & \multirow{5}{*}{0.919} & \multirow{5}{*}{0.004} & \multirow{5}{*}{0.004} \\
\hline & 23 & 0.536 & 0.547 & 0.060 & & & \\
\hline & 30 & 0.522 & 0.552 & 0.110 & & & \\
\hline & 37 & 0.471 & 0.518 & 0.054 & & & \\
\hline & 44 & 0.509 & 0.483 & 0.065 & & & \\
\hline \multirow{5}{*}{ GPx (U/g Hb) } & 0 & 486.4 & 506.7 & 115.3 & \multirow{5}{*}{0.022} & \multirow{5}{*}{0.001} & \multirow{5}{*}{0.857} \\
\hline & 23 & 518.2 & 530.7 & 117.8 & & & \\
\hline & 30 & 380.4 & 434.0 & 97.16 & & & \\
\hline & 37 & 254.5 & 316.9 & 75.62 & & & \\
\hline & 44 & 175.3 & 224.5 & 72.15 & & & \\
\hline \multirow{5}{*}{$\operatorname{MDA}(\mu \mathrm{mol} / \mathrm{L})$} & 0 & 0.265 & 0.269 & 0.037 & \multirow{5}{*}{0.060} & \multirow{5}{*}{0.001} & \multirow{5}{*}{0.599} \\
\hline & 23 & 0.235 & 0.247 & 0.033 & & & \\
\hline & 30 & 0.242 & 0.269 & 0.028 & & & \\
\hline & 37 & 0.241 & 0.248 & 0.041 & & & \\
\hline & 44 & 0.273 & 0.297 & 0.035 & & & \\
\hline
\end{tabular}

TAC, total antioxidant capacity; GPx, blood glutathione peroxidase; $\mathrm{Hb}$, hemoglobin; MDA, malondialdehyde $\mathrm{T}$, treatment; $\mathrm{SD}$, standard deviation. 


\subsection{Scanning Electron Microscopy (SEM)}

The surface structures of adult female $H$. contortus examined by SEM (Figure 3 ) did not differ significantly between the animals fed with SFPs $(n=12)$ and the control group $(n=6)$. The only obvious difference in the treated group was the detachment of the cuticle in the cephalic region (Figure 3(S1)), but only one of the 12 specimens exhibited such damage. The cuticle in the middle part of the body in both groups possessed only physiological longitudinal ridges (Figure 3(S2,C2)), with no wrinkled cuticular surface on any of the worms (Figure 3). Slight protuberances (arrow) were common around the bases of the cervical papillae, but both the treated (Figure 3(S3)) and control (Figure 3(C3)) specimens had this trait. Some debris was near the anal pore of a few specimens in the SPF and control groups (Figure 3(S4,C4)).
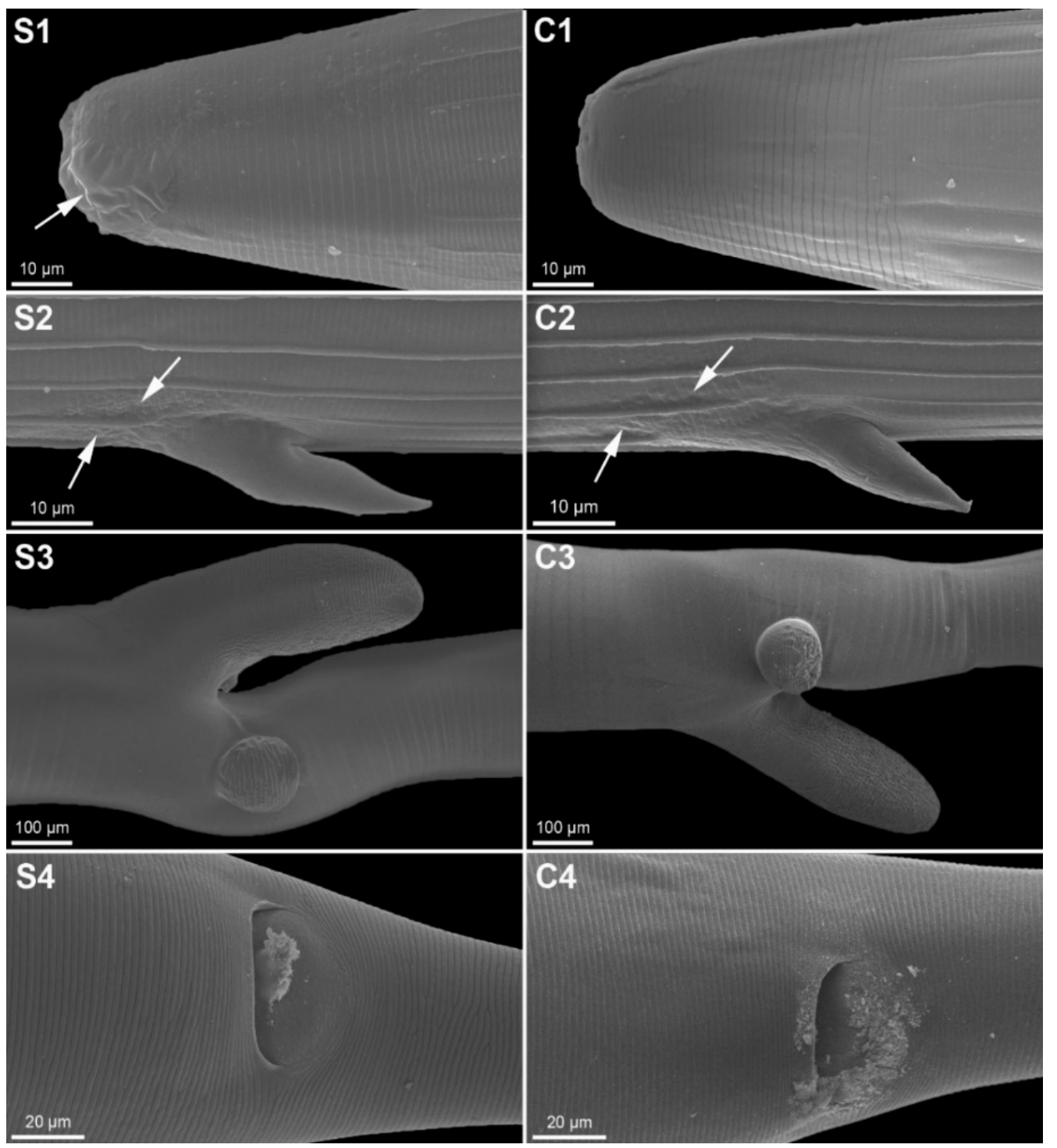

Figure 3. Scanning electron micrographs of adult female Haemonchus contortus isolated from the abomasa of lambs fed with SFPs (S1-S4) and from the control animals (C1-C4). Micrographs show the cephalic region with a detached (arrow) cuticle in the apical part (S1) compared with a control individual (C1), a cervical papilla with slight protuberances around its base (S2,C2), the smooth surface of the posterior part of the body with the vulvar flap and lateral button $(\mathbf{S} 3, \mathbf{C} 3)$, and the terminal part of the body with remnants of debris near the anal pore $(\mathbf{S} 4, \mathbf{C} 4)$. 


\section{Discussion}

We predicted that lambs infected with $H$. contortus and treated with SFPs would have noticeable reductions in FEC and total abomasal worm counts compared to the control lambs. We thus also expected better overall health conditions, demonstrated as a higher LWG in the treated lambs. Tanniferous forages can increase the LWGs of sheep infected with $H$. contortus [19], consistent with our results at the end of the experiment. Our results indicated that the SFP group had a lower parasitic load based on differences in LWG between the groups. This lower load was confirmed not only by significant differences in LWG between groups but also by FECRs and mean worm counts at necropsy. Lower growth rates are generally considered to be an indicator of parasitism in lambs infected with GINs, but plant polyphenols, especially flavonoids, can improve the growth of animals and the quality of animal products [20]. We previously reported that dried plant nutraceuticals containing different amounts of flavonoids and phenolics may [21] or may not [22-24] influence the growth parameters of infected lambs. The SFPs in the present experiment contained $4.62 \mathrm{mg}$ QE/g DM flavonoids. We previously reported flavonoid range of $10-40 \mathrm{~g} / \mathrm{kg}$ DM in herbal nutraceuticals $[22,25,26]$.

The effects on BW and LWG probably depend on the source and variety of polyphenols and on the combination of the multitarget complex bioactive compounds that can work synergistically and antagonistically [26].

The FEC and worm burden during the 14-day administration of SFPs were reduced by 36.7 and $30.6 \%$, respectively, as direct nematocidal effects. Tanniferous feeds can directly affect worm biology and modulate the epidemiology of GIN infections as pharmacologicallike processes [16,27]. The direct anthelmintic effect of the SFPs on the reduction of FEC and the number of adult worms in our experiment is consistent with several other trials [28-30]. Sainfoin diets, (i.e. dried and ensiled) consumed in these trials for $16 \mathrm{~d}$ by lambs infected with $H$. contortus reduced the number of adult worms by 47 and $49 \%$, respectively, and the FEC was reduced by 58 and $48 \%$, respectively [28]. The inclusion of sainfoin (20\%) in ground lucerne pellets to the diets of lambs infected with $H$. contortus for $30 \mathrm{~d}$ reduced both FEC (54\%) and the number of adult worms (13\%) [29]. A similar study with calves receiving sainfoin pellets for $42 \mathrm{~d}$ post-infection reported reduced parasite populations of Ostertagia ostertagi by 50\% [30]. In our experiment, the reductions in FEC and the number of adult parasites were lower compared to the above studies. We administered the SFP diet to a group of animals from $30 \mathrm{~d}$ after the experimental infection when the parasites had developed into the adult stage, whereas the sainfoin diet in the other studies [28-30] was administered to the animals from, or several days before, the experimental infection. The prolonged administration of the sainfoin diet could thus also have affected the developing larval stages of the parasites, which could increase the efficiency of the diet.

The aqueous extract of the SFPs in our study had a strong ovicidal effect $(>70 \%)$ at concentrations $\geq 6.25 \mathrm{mg} / \mathrm{mL}$ in the EHT. Dried tanniferous plants used as fodder or in in vitro tests can directly affect nematode species and their stages [31-33], probably due to the size and the percentage of flavan-3-ols of prodelphinidin-type CTs that influence anti-parasitic activity against nematodes [34]. The anthelmintic activity of CTs against GINs may be increased by the addition of flavonoids [35], and sainfoin itself contains beneficial flavonoids that interfere with the biology of $H$. contortus [36], consistent with our results. The use of dry medicinal plants with high contents of flavonoids against $H$. contortus in vivo can have an indirect anthelmintic effect that can contribute to an increase in the resistance of lambs to nematode infection [22-24]. The anthelmintic effects of the plant extract in vitro and the sensitivity of the methodological procedures used should be taken into account for the overall evaluation of plants with bioactive components [37,38].

The level of IgA antibodies against $H$. contortus in our experiment increased significantly over time after infection in both groups. A study with a longer (six weeks) consumption of sainfoin hay described an enhanced local immune response to Trichostrongylus colubriformis and a significant reduction in the FEC in sheep [39]. IgA activity against the parasite Teladorsagia circumcincta in sheep has also been associated with a reduction in fertility and 
the length of adult parasites [40]. Low IgA levels in infected animals are associated with low-intensity infections or with heavy infections, when most of the mucosal IgA is bound to parasite antigens [41]. The higher levels of IgA and higher EPx activity in our experiment responded strongly to infection and were correlated with decreased FECs of the animals. The EPx enzyme is involved in killing parasites and implicates eosinophils in the direct control of parasitic infections [42,43]. Our results suggest that a longer time $(>14 \mathrm{~d})$ of consumption of sainfoin pellets by infected animals is needed to produce a prominent antibody response to the treatment. Tanniferous plants have immunomodulatory effects against GINs, but helminths secrete an extremely broad spectrum of immunoregulatory molecules to ensure survival inside their host, which can also have consequences on the immune responses of host animals [44].

Our results indicated that the activity of GPx in the blood decreased continually from the beginning of the SFP treatment (i.e., 30-37 d post-infection). The serum level of MDA, as a marker of oxidative stress, was not affected by the treatment, but lipid oxidation in the SFP treatment tended to decrease. SFPs decreased blood GPx activity from D23 indicating that lower antioxidant activity is needed for lambs treated with SFPs to maintain the same oxidative status. These findings are consistent with our prior results using medicinal plants with a wide range of bioactive compounds [22-24] that possess the antioxidant potential and are supplements for diseases associated with oxidative stress [45]. The antioxidant status of lambs probably closely depends on the efficiency of absorption, concentration, and metabolic transformation of phytochemicals and the environment [46]. Some medicinal plants are often characterized as poisonous and medicinal, but each of the medicinal plants, both as mixtures and SFPs, have been tested by in vitro rumen fermentation without adverse effects on the rumen microbiome [21-24]. Another benefit of medical treatment is the use of plants as substitutes for synthetic drugs to which parasites have developed resistance in the past.

SEM recently became a tool to demonstrate the possible anthelmintic effects of nutraceutical plants in multiple studies [47-49]. Studies on ultrastructural changes have mostly been conducted under in vitro conditions with various plants. The effects of Biophytum petersianum on $H$. contortus, such as wrinkling on the cuticular surface followed by exfoliation of the tegument on the tail section, have been described [50]. The main changes to female $H$. contortus after in vitro exposure to SFPs were on the cuticle and in the vulval region and buccal area [27]. Less data, however, are available on the in vivo effects of herbal substances on GINs. The damaging effects of sainfoin on third-stage larvae [51] and adult $H$. contortus [52] have been described using transmission electron microscopy, such as the detachment of cuticles and changes in intestinal and muscular cells that can negatively affect the viability of parasites. Ultrastructural changes after in vivo treatment with CTs have mostly been reported as local cuticular damage and changes on buccal capsules [30,53]. One of the most common features in our worms were protuberances around the bases of the cervical papillae, which were not mentioned in other studies, but the control group also had this feature. The cuticle across parasites from both groups were smooth with physiological longitudinal ridges. Only one more pronounced cuticular damage (Figure 3(S1)) was observed in worms from the SFP group, but the sample size was too small for confirming the overall effect. Cuticular wrinkling has been reported in the majority of studies of ultrastructural changes $[48,49,54,55]$. Aggregates near the buccal capsule, vulva, and anus have been described as a change in treated worms [53], but we also found these traits in the control group. A correlation between the length of exposure to CTs and ultrastructural changes that were more prominent after $77 \mathrm{~d}$ of treatment in comparison with $28 \mathrm{~d}$ has also been reported [30]. We cannot confirm the effect of SFPs on the surface structures of $H$. contortus after $14 \mathrm{~d}$ of treatment, because we did not find any of the changes reported in previous SEM studies. 


\section{Materials and Methods}

\subsection{Ethics Statement}

This study was conducted following the guidelines of the Declaration of Helsinki and national legislation in the Slovak Republic (G.R. 377/2012; Law 39/2007) for the care and use of research animals. The experimental protocol was approved by the Ethical Committee of the Institute of Parasitology of the Slovak Academy of Sciences on 22 November 2020 (protocol code 2020/21).

\subsection{Experimental Design, Diets, and Experimental Infection}

Twenty-four female Improved Valachian lambs, all 3-4 months old with no grazing history and a mean weight of $14.58 \pm 1.689 \mathrm{~kg}$, were housed in common stalls on a sheep farm (PD Ružín-Ružín farm, Kysak, Slovakia) with free access to water. The animals were dewormed with the recommended dose of albendazole (Albendavet 1.9\% susp. a.u.v, DIVASA-FARMAVIC S.A., Barcelona, Spain) $14 \mathrm{~d}$ before the start of the trial and were kept indoors to maintain parasite-free conditions. The diet of the animals included meadow hay ad libitum and $300 \mathrm{~g}$ of dry matter (DM)/d of a commercial concentrate, Mikrop ČOJ (MIKROP, Čebín, Czech Republic). After the acclimation period, the lambs were infected with 5000 third-stage larvae of the $H$. contortus MHCo1 strain susceptible to anthelmintics [22]. The lambs were divided into two groups of twelve animals each (one stall per group) on D30 after infection when all parasites had matured to the adult stage: animals treated with sainfoin pellets (SFPs, $600 \mathrm{~g}$ DM/d/animal) and untreated animals (control, meadow hay, $600 \mathrm{~g} \mathrm{DM} / \mathrm{d} /$ animal). SFPs were obtained from a commercial source (NATURE'S BEST, EQUOVIS GmbH, Münster, Germany). This treatment scheme continued for $14 \mathrm{~d}$. Animals were housed in collective stalls according to dietary treatment ( $n=12$ /stall) and adequate access to water and feeder space was provided for each animal. Feeders were placed and designed to allow easy access to the complete ratio for all lambs in each group and also to avoid wasting feed. One-sided access to the feeding troughs allowed $40-45 \mathrm{~cm}$ per lamb. The animals completely consumed the concentrate and SFPs and no food rejection was noted. All animals were humanely slaughtered at the end of the trial (D44) following the rules of the European Commission (Council Regulation 1099/2009) for slaughtering procedures [56].

\subsection{Chemical Tests of Sainfoin Pellets (SFPs)}

Chemical tests for the screening of SFP bioactive compounds were carried out in aqueous extracts (saponins, terpenoids) or ethanolic extracts (tannins, alkaloids, flavonoids, steroids) (Table 5) using standard procedures [57].

Table 5. Chemical composition of the aqueous and ethanolic extracts of the sainfoin pellets (SFPs).

\begin{tabular}{ccccccc} 
& Tannins & Saponins & Alkaloids & Terpenoids & Flavonoids & Steroids \\
\hline SFPs & + & - & - & + & + & - \\
\hline,+ bioactive compounds present; $;$ &,- bioactive compounds not present.
\end{tabular}

The total phenolic and flavonoid content in the SFP extract was $13.86 \mathrm{mg}$ TAE/g DM and $4.62 \mathrm{mg} \mathrm{QE} / \mathrm{g} \mathrm{DM}$, respectively. The SFP extract was prepared as described earlier by Petrič et al. (2020). The sainfoin pellets $(10 \mathrm{~g})$ were crushed and mixed with $100 \mathrm{ml}$ of ethanol $(70 \%)$ using a magnetic stirrer at room temperature for $24 \mathrm{~h}$. Thereafter, the extract was filtered throughout Whatman filter paper No. 1 to obtain extract without plant particles. The residue was re-extracted twice and the pooled extract was used for the analysis of total phenolics and flavonoids content. The concentration of phenolic compounds in the extract was determined by Folin-Ciocalteu colorimetric assay [58] and expressed as mg tannic acids equivalents per gram of dried weight sample (mg TAE/g DM). The total flavonoids content in the SFP extract was determined [59] and results were expressed as mg quercetin equivalents per gram of dried weight sample (mg QE/g DW). 


\subsection{Fecal Egg Count and Animal Weighing}

Fecal samples were collected rectally on D18, D23, D26, D30, D33, D37, D40, and D44 post-infection. The number of eggs per gram (EPG) of feces was quantified using the McMaster method previously described [60]. The lambs were weighed on D0 and D44.

\subsection{Counts of Adult Worms}

After slaughtering on D44, a helminthological necropsy was performed to count the total number of worms. The abomasum of each animal was removed and dissected, and the abomasal contents were washed with warm physiological saline and emptied into a jar. The contents of the jar were mixed continuously to prevent the clustering of nematodes, and washings were brought up to a volume of two liters with water. Two $40-\mathrm{mL}$ aliquots were collected and fixed with helminthological iodine, and the recovered $H$. contortus adults were counted and classified as male or female. Female fecundity (egg production per worm) on D44 was then calculated as EPG on D44 in both groups divided by the number of female worms found at necropsy in the corresponding groups.

\subsection{Egg Hatch Test}

An EHT was performed to determine the ovicidal activity of the aqueous extract prepared from ground SFPs, as described previously [25]. Eggs of susceptible H. contortus were isolated from feces freshly collected from the rectums of lambs from the untreated control group. Final concentrations of the SFP aqueous extracts used in the EHT were 50, 25, $12.5,6.25,3.125$, and $1.563 \mathrm{mg} / \mathrm{mL}$. The EHTs were performed in six independent determinations. The concentrations of extract that prevented 50 and $99 \%$ of the eggs from hatching (median effective dose, $\mathrm{ED}_{50}$ ) were established, and ovicidal activity was calculated.

\subsection{Antibody Responses}

Mucus samples obtained from the abomasa were used to determine the levels of total IgA. Mucus was collected after necropsy by light scraping of the abomasal mucosa using a glass slide. The mucus was diluted in a buffer $(\mathrm{pH} 7.1 ; \mathrm{Na} 2 \mathrm{HPO} 40.1 \mathrm{M} ; \mathrm{NaCl} 0.05 \mathrm{M}$; NaN3 $3 \mathrm{mM}$; PMSF $1 \mathrm{mM}$; EDTA $5 \mathrm{mM}$ ) at the rate of $2.5 \mathrm{~mL} / \mathrm{g}$ mucus, homogenized, and centrifuged at $18,000 \times$ g at $4{ }^{\circ} \mathrm{C}$ for $30 \mathrm{~min}$ [61]. The supernatant was collected and stored at $-20^{\circ} \mathrm{C}$ until analysis. Adult worms were harvested from the abomasa of the infected lambs. The excretory/secretory products (ESPs) of adult $H$. contortus were obtained as described by [23], with some modifications. Freshly collected adults were washed five times in warm phosphate-buffered saline ( $\mathrm{pH}$ 7.4). The parasites were then transferred at a concentration of 500 adults $/ 20 \mathrm{~mL}$ to RPMI 1640 medium containing $100 \mathrm{U} / \mathrm{mL}$ penicillin and $100 \mu \mathrm{g} / \mathrm{mL}$ streptomycin (Sigma-Aldrich, Hamburg, Germany) and incubated in $5 \% \mathrm{CO}_{2}$ at $37^{\circ} \mathrm{C}$ for $4 \mathrm{~h}$. The worms were then removed, and the medium containing the ESPs was centrifuged at $20,000 \times g$ at $4{ }^{\circ} \mathrm{C}$ for $15 \mathrm{~min}$. The supernatant with the ESPs was centrifuged in $3000 \mathrm{MWCO}$ VIVASPIN tubes (Sartorius, Goettingen, Germany) at $4000 \times g$ at $4{ }^{\circ} \mathrm{C}$ for $60 \mathrm{~min}$ and stored at $-20^{\circ} \mathrm{C}$. The ESP protein concentration was measured using the Bradford protein assay (Bio-Rad Laboratories, Munich, Germany). The levels of total IgA in the mucus and serum and specific IgG and IgM against $H$. contortus in the serum were determined using a rabbit anti-sheep IgA antibody (Bethyl Laboratories, Inc., Montgomery, AL, USA) or an ESP antigen in an indirect enzyme-linked immunosorbent assay (ELISA), similar to a previously described method [62]. H. contortus ESPs were diluted to a final concentration of $5 \mu \mathrm{g} / \mathrm{mL}$ for IgG and IgM. Anti-sheep IgA antibody for serum and mucus IgA was diluted to concentration 1:500. The serum samples were diluted 1:100, the mucus samples were diluted 1:10, and horseradish peroxidase-conjugates rabbit anti-sheep IgG (Sigma-Aldrich, Hamburg, Germany), rabbit anti-sheep IgM H\&L (Abcam, Cambridge, MA, USA), and rabbit anti-sheep IgA (Bio-Rad Laboratories, Inc., Kidlington, UK) were diluted 1:2000, 1:50,000, and 1:10,000, respectively. The results are expressed as optical densities measured using an Apollo 11 LB913 Elisa absorbance reader (Berthold Technologies GmbH \& Co. KG, 
Bad Wildbad, Germany). Sheep eosinophil peroxidase (EPX) level was measured using an ELISA kit (MyBioSource Ltd., San Diego, CA, USA) with a sensitivity of $1.0 \mathrm{ng} / \mathrm{mL}$.

\subsection{Antioxidant Parameters}

The activity of glutathione peroxidase (GPx) in the blood, total antioxidant capacity (TAC) in the serum, and the serum concentration of malondialdehyde (MDA) were determined as previously described [11].

\subsection{Scanning Electron Microscopy (SEM)}

Worms were randomly collected during necropsy from the SFP treated group and control animals. Adult specimens selected for SEM were rinsed in saline, fixed in a $4 \%$ formaldehyde solution near the boiling point, and stored in 70\% non-denatured ethanol. Each specimen was cut into three parts (anterior, middle, and posterior), which were dehydrated in an ascending series of concentrations of ethanol $(80,90,96$, and $100 \%$; $15 \mathrm{~min}$. in each concentration), chemically dried in 1,1,1,3,3,3-hexamethyldisilazane (Merck, Darmstadt, German), and gold-sputtered using a JEOL JFC 1300 auto fine coater (JEOL Ltd., Tokyo, Japan). The SEM micrographs were captured using a JEOL JSM 6510LA.

\subsection{Statistical Analysis}

We evaluated the efficacy of the SFP treatment using a FECRT (\%) and the formula recommended by the World Association for the Advancement of Veterinary Parasitology (WAAVP) [60]: $(1-[\mathrm{T} \div \mathrm{C}]) \times 100$, where $\mathrm{T}$ is the arithmetic mean EPG for the SFP group $14 \mathrm{~d}$ after treatment and $\mathrm{C}$ is the arithmetic mean EPG for the control group at D44. A logit model of regression analysis was applied on egg hatch data to express an $\mathrm{ED}_{50}$ and $\mathrm{ED}_{99}$ concentration for each $\mathrm{EHT}$. The differences between egg production (EPGs) in the groups on different sampling days after treatment, differences between the number of worms in the abomasum in the groups of animals, the ovicidal effect on parasite eggs in the EHT, and differences between the levels of total IgA in the mucus were assessed using Student's $t$-tests. The antibody responses and antioxidant parameters were statistically analyzed using analyses of variance (ANOVAs) (GraphPad Prism 8; GraphPad Software, Inc., San Diego, CA, USA) as a repeated-measures mixed model representing the two groups and sampling days. Differences between the groups were identified using a two-way ANOVA. Results were considered significant at $p<0.05$.

\section{Conclusions}

The treatment of infected lambs with SFPs for $14 \mathrm{~d}$ improved the parameters of production and directly affected the dynamics of infection without strong antibody responses of the treated animals. The mobilization of the antioxidant defensive system, however, suggested that the animals were able to protect themselves against the new oxidative conditions. Dietary antioxidants in the form of SFPs were available to sustain the antibody response and thus indirectly improved the resistance of the animals against $H$. contortus.

Author Contributions: Conceptualization, Z.V. and M.V.; validation, M.B., E.D., K.Č. and D.B. (Dominika Batt'ányi); formal analysis, D.P., K.K., M.U.D. and A.K.; investigation, M.K.; resources, M.K.; data curation, Z.V.; writing-original draft preparation, M.K.; writing-review and editing, Z.V. and M.V.; visualization, D.B. (Daniel Barčák); supervision, Z.V. and M.V.; project administration, M.V.; funding acquisition, M.V. All authors have read and agreed to the published version of the manuscript.

Funding: This research was funded by the Slovak Research and Development Agency (www.apvv.sk, accessed on 1 July 2019) (APVV 18-0131) and the SAS Programme for PhD students'grants (www. doktogrant.sav.sk, accessed on 1 June 2020) (DoktoGrant APP0162).

Institutional Review Board Statement: The study was conducted following the guidelines of the Declaration of Helsinki and was approved by the Ethical Committee of the Institute of Parasitology of the Slovak Academy of Sciences on 22 November 2020 (protocol code 2020/21).

Data Availability Statement: Data are available upon reasonable request to the corresponding author. 
Acknowledgments: The authors are grateful to Bc. V. Venglovská, S. Spišáková, P. Jerga, and G. Benkovský for their laboratory and technical support. The authors acknowledge the Englishlanguage editor William Blackhall for revising the manuscript. (https: / www.globalbiologicalediting. com/editor/index.html, accessed on 2 January 2022).

Conflicts of Interest: The authors declare no conflict of interest. The funders had no role in the design of the study, in the collection, analyses, or interpretation of the data, in the writing of the manuscript, or in the decision to publish the results.

\section{References}

1. Papadopoulos, E. Anthelmintic resistance in sheep nematodes. Small Rumin. Res. 2008, 76, 99-103. [CrossRef]

2. Waller, P.J. From discovery to development: Current industry perspectives for the development of novel methods of helminth control in livestock. Vet. Parasitol. 2006, 139, 1-14. [CrossRef] [PubMed]

3. Besier, R.B.; Kahn, L.P.; Sargison, N.D.; Van Wyk, J.A. The pathophysiology, ecology and epidemiology of Haemonchus contortus infection in small ruminants. Adv. Parasitol. 2016, 93, 95-143. [CrossRef] [PubMed]

4. Balic, A.; Bowles, V.M.; Meeusen, E.N. The immunobiology of gastrointestinal nematode infections in ruminants. Adv. Parasitol. 2000, 45, 181-241. [CrossRef]

5. Colditz, I.G. Six costs of immunity to gastrointestinal nematode infections. Parasite Immunol. 2008, 30, 63-70. [CrossRef]

6. Coop, R.L.; Holmes, P.H. Nutrition and parasite interaction. Int. J. Parasitol. 1996, 26, 951-962. [CrossRef]

7. Hoste, H.; Torres-Acosta, J.F.; Quijada, J.; Chan-Perez, I.; Dakheel, M.M.; Kommuru, D.S.; Mueller-Harvey, I.; Terrill, T.H. Interactions between nutrition and infections with Haemonchus contortus and related gastrointestinal nematodes in small ruminants. Adv. Parasitol. 2016, 93, 239-351. [CrossRef]

8. Williams, A.R.; Klaver, E.J.; Laan, L.C.; Ramsay, A.; Fryganas, C.; Difborg, R.; Kringel, H.; Reed, J.D.; Mueller-Harvey, I.; Skov, S.; et al. Co-operative suppression of inflammatory responses in human dendritic cells by plant proanthocyanidins and products from the parasitic nematode Trichuris suis. Immunology 2017, 150, 312-328. [CrossRef]

9. Tedeschi, L.O.; Muir, J.P.; Naumann, H.D.; Norris, A.B.; Ramírez-Restrepo, C.A.; Mertens-Talcott, S.U. Nutritional aspects of ecologically relevant phytochemicals in ruminant production. Front. Vet. Sci. 2021, 8, 628445. [CrossRef]

10. Machado, V.; Da Silva, A.S.; Schafer, A.S.; Aires, A.R.; Tonin, A.A.; Oliveira, C.B.; Hermes, C.L.; Almeida, T.C.; Moresco, R.N.; Stefani, L.M.; et al. Relationship between oxidative stress and pathological findings in abomasum of infected lambs by Haemonchus contortus. Pathol. Res. Pract. 2014, 210, 812-817. [CrossRef]

11. Čobanová, K.; Váradyová, Z.; Grešáková, L'; Kucková, K.; Mravčáková, D.; Várady, M. Does herbal and/or zinc dietary supplementation improve the antioxidant and mineral status of lambs with parasite infection? Antioxidants 2020, 9, 1172. [CrossRef] [PubMed]

12. Mravčáková, D.; Sobczak-Filipiak, M.; Váradyová, Z.; Kucková, K.; Čobanová, K.; Maršík, P.; Tauchen, J.; Vadlejch, J.; Mickiewicz, M.; Kaba, J.; et al. Effect of Artemisia absinthium and Malva sylvestris on antioxidant parameters and abomasal histopathology in lambs experimentally infected with Haemonchus contortus. Animals 2021, 11, 462. [CrossRef]

13. Yahfoufi, N.; Alsadi, N.; Jambi, M.; Matar, C. The immunomodulatory and anti-inflammatory role of polyphenols. Nutrients 2018, 10, 1618. [CrossRef] [PubMed]

14. Paolini, V.; De La Farge, F.; Prevot, F.; Dorchies, P.; Hoste, H. Effects of the repeated distribution of sainfoin hay on the resistance and the resilience of goats naturally infected with gastrointestinal nematodes. Vet. Parasitol. 2005, 127, 277-283. [CrossRef] [PubMed]

15. Williams, A.R.; Fryganas, C.; Ramsay, A.; Mueller-Harvey, I.; Thamsborg, S.M. Direct anthelmintic effects of condensed tannins from diverse plant sources against Ascaris suum. PLoS ONE 2014, 9, e97053. [CrossRef]

16. Hoste, H.; Torres-Acosta, J.F.; Sandoval-Castro, C.A.; Mueller-Harvey, I.; Sotiraki, S.; Louvandini, H.; Thamsborg, S.M.; Terrill, T.H. Tannin containing legumes as a model for nutraceuticals against digestive parasites in livestock. Vet. Parasitol. 2015, $212,5-17$. [CrossRef]

17. Spiegler, V.; Liebau, E.; Hensel, A. Medicinal plant extracts and plant-derived polyphenols with anthelmintic activity against intestinal nematodes. Nat. Prod. Rep. 2017, 34, 627-643. [CrossRef]

18. Gaudin, E.; Simon, M.; Quijada, J.; Schelcher, F.; Sutra, J.-F.; Lespine, A.; Hoste, H. Efficacy of sainfoin (Onobrychis viciifolia) pellets against multi resistant Haemonchus contortus and interaction with oral ivermectin: Implications for on-farm control. Vet. Parasitol. 2016, 227, 122-129. [CrossRef]

19. Singh, S.; Pathak, A.K.; Sharma, R.K.; Khan, M. Effect of tanniferous leaf meal based multi-nutrient blocks on feed intake, hematological profile, immune response, and body weight changes in Haemonchus contortus infected goats. Vet. World 2015, 8 , 572-579. [CrossRef]

20. Tufarelli, V.; Casalino, E.; D'Alessandro, A.G.; Laudadio, V. Dietary phenolic compounds: Biochemistry, metabolism and significance in animal and human health. Curr. Drug Metab. 2017, 18, 905-913. [CrossRef]

21. Váradyová, Z.; Kišidayová, S.; Čobanová, K.; Grešáková, L'.; Babják, M.; Königová, A.; Urda Dolinská, M.; Várady, M. The impact of a mixture of medicinal herbs on ruminal fermentation, parasitological status and hematological parameters of the lambs experimentally infected with Haemonchus contortus. Small Rumin. Res. 2017, 151, 124-132. [CrossRef] 
22. Váradyová, Z.; Mravčáková, D.; Babják, M.; Bryszak, M.; Grešáková, L’.; Čobanová, K.; Kišidayová, S.; Plachá, I.; Königová, A.; Cieslak, A.; et al. Effects of herbal nutraceuticals and/or zinc against Haemonchus contortus in lambs experimentally infected. BMC Vet. Res. 2018, 14, 78. [CrossRef] [PubMed]

23. Mravčáková, D.; Váradyová, Z.; Kopčáková, A.; Čobanová, K.; Grešáková, Ĺ.; Kišidayová, S.; Babják, M.; Urda Dolinská, M.; Dvorožňáková, E.; Königová, A.; et al. Natural chemotherapeutic alternatives for controlling of haemonchosis in sheep. BMC Vet. Res. 2019, 15, 302. [CrossRef] [PubMed]

24. Komáromyová, M.; Mravčáková, D.; Petrič, D.; Kucková, K.; Babják, M.; Dolinská, M.U.; Königová, A.; Mad’arová, M.; Pruszyńska-Oszmałek, E.; Cieslak, A.; et al. Effects of medicinal plants and organic selenium against ovine haemonchosis. Animals 2021, 11, 1319. [CrossRef]

25. Váradyová, Z.; Pisarčíková, J.; Babják, M.; Hodges, A.; Mravčáková, D.; Kišidayová, S.; Königová, A.; Vadlejch, J.; Várady, M. Ovicidal and larvicidal activity of extracts from medicinal-plants against Haemonchus contortus. Exp. Parasitol. 2018, 195, 71-77. [CrossRef]

26. Mravčáková, D.; Komáromyová, M.; Babják, M.; Urda Dolinská, M.; Königová, A.; Petrič, D.; Čobanová, K.; Ślusarczyk, S.; Cieslak, A.; Várady, M.; et al. Anthelmintic activity of wormwood (Artemisia absinthium L.) and mallow (Malva sylvestris L.) against Haemonchus contortus in sheep. Animals 2020, 10, 219. [CrossRef]

27. Hoste, H.; Martinez-Ortiz-De-Montellano, C.; Manolaraki, F.; Brunet, S.; Ojeda-Robertos, N.; Fourquaux, I.; Torres-Acosta, J.F.; Sandoval-Castro, C.A. Direct and indirect effects of bioactive tannin-rich tropical and temperate legumes against nematode infections. Vet. Parasitol. 2012, 186, 18-27. [CrossRef]

28. Heckendorn, F.; Häring, D.A.; Maurer, V.; Zinsstag, J.; Langhans, W.; Hertzberg, H. Effect of sainfoin (Onobrychis viciifolia) silage and hay on established populations of Haemonchus contortus and Cooperia curticei in lambs. Vet. Parasitol. 2006, 142, 293-300. [CrossRef]

29. Valderrábano, J.; Calvete, C.; Uriarte, J. Effect of feeding bioactive forages on infection and subsequent development of Haemonchus contortus in lamb faeces. Vet. Parasitol. 2010, 172, 89-94. [CrossRef]

30. Desrues, O.; Peña-Espinoza, M.; Hansen, T.V.; Enemark, H.L.; Thamsborg, S.M. Anti-parasitic activity of pelleted sainfoin (Onobrychis viciifolia) against Ostertagia ostertagi and Cooperia oncophora in calves. Parasites Vectors 2016, 9, 329. [CrossRef]

31. Athanasiadou, S.; Kyriazakis, F.; Jackson, F.; Coop, R.I. Direct anthelmintic effects of condensed tannins towards different gastrointestinal nematodes of sheep: In vitro and in vivo studies. Vet. Parasitol. 2001, 99, 205-219. [CrossRef]

32. Paolini, V.; Fouraste, I.; Hoste, H. In vitro effects of three woody plant and sainfoin extracts on 3rd-stage larvae and adult worms of three gastrointestinal nematodes. Parasitology 2004, 129, 69-77. [CrossRef]

33. Hoste, H.; Jackson, F.; Athanasiadou, S.; Thamsborg, S.M.; Hoskin, S.O. The effects of tannin-rich plants on parasitic nematodes in ruminants. Trends Parasitol. 2006, 22, 253-261. [CrossRef] [PubMed]

34. Desrues, O.; Fryganas, C.; Ropiak, H.M.; Mueller-Harvey, I.; Enemark, H.L.; Thamsborg, S.M. Impact of chemical structure of flavanol monomers and condensed tannins on in vitro anthelmintic activity against bovine nematodes. Parasitology 2016, 143, 444-454. [CrossRef] [PubMed]

35. Klongsiriwet, C.; Quijada, J.; Williams, A.R.; Mueller-Harvey, I.; Williamson, E.M.; Hoste, H. Synergistic inhibition of Haemonchus contortus exsheathment by flavonoid monomers and condensed tannins. Int. J. Parasitol. Drugs Drug Resist. 2015, 5, 127-134. [CrossRef] [PubMed]

36. Barrau, E.; Fabre, N.; Fouraste, I.; Hoste, H. Effect of bioactive compounds from sainfoin (Onobrychis viciifolia Scop.) on the in vitro larval migration of Haemonchus contortus: Role of tannins and flavonol glycosides. Parasitology 2005, 131, 531-538. [CrossRef] [PubMed]

37. Alonso-Díaz, M.A.; Torres-Acosta, J.F.J.; Sandoval-Castro, C.A.; Hoste, H. Comparing the sensitivity of two in vitro assays to evaluate the anthelmintic activity of tropical tannin rich plant extracts against Haemonchus contortus. Vet. Parasitol. 2011, 181, 360-364. [CrossRef] [PubMed]

38. Quijada, J.; Fryganas, C.; Ropiak, H.M.; Ramsay, A.; Mueller-Harvey, I.; Hoste, H. Anthelmintic activities against Haemonchus contortus or Trichostrongylus colubriformis from small ruminants are influenced by structural features of condensed tannins. J. Agric. Food Chem. 2015, 63, 6346-6354. [CrossRef]

39. Ríos-De Álvarez, L.; Greer, A.; Jackson, F.; Athanasiadou, S.; Kyriazakis, I.; Huntley, J. The effect of dietary sainfoin (Onobrychis viciifolia) on local cellular responses to Trichostrongylus colubriformis in sheep. Parasitology 2008, 135, 1117-1124. [CrossRef]

40. McRae, K.M.; Good, B.; Hanrahan, J.P.; Glynn, A.; O'Connell, M.J.; Keane, O.M. Response to Teladorsagia circumcincta infection in Scottish Blackface lambs with divergent phenotypes for nematode resistance. Vet. Parasitol. 2014, 206, 200-207. [CrossRef]

41. De Cisneros, J.; Matthews, L.; Mair, C.; Stefan, T.; Stear, M. The transfer of IgA from mucus to plasma and the implications for diagnosis and control of nematode infections. Parasitology 2014, 141, 875-879. [CrossRef] [PubMed]

42. Doligalska, M.; Moskwa, B.; Stear, M.J. Relationships among peripheral eosinophilia, eosinophil peroxidase activity, interleukin5 concentration and faecal nematode egg count during natural, mixed gastrointestinal nematode infection. Vet. Immunol. Immunopathol. 1999, 70, 299-308. [CrossRef]

43. Jenvey, C.J.; Alenizi, D.; Almasi, F.; Cairns, C.; Holmes, A.; Sloan, S.; Stear, M.J. Bioinformatic analysis of eosinophil activity and its implications for model and target species. Parasitology 2020, 147, 393-400. [CrossRef] [PubMed]

44. Wiedemann, M.; Voehringer, D. Immunomodulation and immune escape strategies of gastrointestinal helminths and schistosomes. Front. Immunol. 2020, 11, 2271. [CrossRef] [PubMed] 
45. Singh, A.; Singh, S.; Prasad, S.M. Role of medicinal plants for health perspective: Special references to antioxidant potential. J. Chem. Biol. Ther. 2016, 1, 106. [CrossRef]

46. Surai, P.F. Polyphenol compounds in the chicken/animal diet: From the past to the future. J. Anim. Physiol. Anim. Nutr. 2014, 98, 19-31. [CrossRef] [PubMed]

47. Ribeiro, W.L.C.; Andre, W.P.P.; Cavalcante, G.S.; de Araújo-Filho, J.V.; Santos, J.M.L.; Macedo, I.T.F.; de Melo, J.V.; de Morais, S.M.; Bevilaqua, C.M.L. Effects of Spigelia anthelmia decoction on sheep gastrointestinal nematodes. Small Rumin. Res. 2017, 153, 146-152. [CrossRef]

48. Adamu, M.; Mukandiwa, L.; Awouafack, M.D.; Ahmed, A.S.; Eloff, J.N.; Naidoo, V. Ultrastructure changes induced by the phloroglucinol derivative agrimol G isolated from Leucosidea sericea in Haemonchus contortus. Exp. Parasitol. 2019, $207,107780$. [CrossRef] [PubMed]

49. Cavalcante, G.S.; Morais, S.M.; André, W.P.P.; Araújo-Filho, J.V.; Muniz, C.R.; Rocha, L.O.; Ribeiro, W.L.C.; Rodrigues, A.L.M.; de Oliveira, L.M.B.; Bevilaqua, C.M.L.; et al. Chemical constituents of Calotropis procera latex and ultrastructural effects on Haemonchus contortus. Braz. J. Vet. Parasitol. 2020, 29, e001320. [CrossRef]

50. Sambodo, P.; Prastowo, J.; Kurniasih, K.; Indarjulianto, S. In vitro potential anthelmintic activity of Biophytum petersianum on Haemonchus contortus. Vet. World 2018, 11, 1-4. [CrossRef]

51. Brunet, S.; Fourquaux, I.; Hoste, H. Ultrastructural changes in the third-stage, infective larvae of ruminant nematodes treated with sainfoin (Onobrychis viciifolia) extract. Parasitol. Int. 2011, 60, 419-424. [CrossRef] [PubMed]

52. Martínez-Ortiz-de-Montellano, C.; Torres-Acosta, J.F.J.; Fourquaux, I.; Sandoval-Castro, C.A.; Hoste, H. Ultrastructural study of adult Haemonchus contortus exposed to polyphenol-rich materials under in vivo conditions in goats. Parasite 2019, 26, 65. [CrossRef] [PubMed]

53. Martínez-Ortíz-de-Montellano, C.; Arroyo-López, C.; Fourquaux, I.; Torres-Acosta, J.F.; Sandoval-Castro, C.A.; Hoste, H. Scanning electron microscopy of Haemonchus contortus exposed to tannin-rich plants under in vivo and in vitro conditions. Exp. Parasitol. 2013, 133, 281-286. [CrossRef] [PubMed]

54. Kommuru, D.S.; Whitley, N.C.; Miller, J.E.; Mosjidis, J.A.; Burke, J.M.; Gujja, S.; Mechineni, A.; Terrill, T.H. Effect of Sericea lespedeza leaf meal pellets on adult female Haemonchus contortus in goats. Vet. Parasitol. 2015, 207, 170-175. [CrossRef]

55. Andre, W.P.; Ribeiro, W.L.; Cavalcante, G.S.; dos Santos, J.M.; Macedo, I.T.; de Paula, H.C.; de Freitas, R.M.; de Morais, S.M.; de Melo, J.V.; Bevilaqua, C.M. Comparative efficacy and toxic effects of carvacryl acetate and carvacrol on sheep gastrointestinal nematodes and mice. Vet. Parasitol. 2016, 218, 52-58. [CrossRef] [PubMed]

56. European Commission (EC). Council Regulation (EC) 1099/2009 of 24 September 2009 on the Protection of Animals at the Time of Killing. Off. J. Eur. Union 2009, L 303, 1-30.

57. Jaradat, N.; Hussen, F.; Al Ali, A. Preliminary phytochemical screening, quantitative estimation of total flavonoids, total phenols and antioxidant activity of Ephedra alata Decne. J. Mater. Environ. Sci. 2015, 6, 1771-1778.

58. Proestos, C.; Lytoudi, K.; Mavromelanidou, O.K.; Zoumpoulakis, P.; Sinanoglou, V.J. Antioxidant capacity of selected plant extracts and their essential oils. Antioxidants 2013, 2, 11-22. [CrossRef]

59. Chang, C.C.; Yang, M.H.; Wen, H.M.; Chern, J.C. Estimation of total flavonoid content in propolis by two complementary colorimetric methods. J. Food Drug Anal. 2002, 10, 178-182. [CrossRef]

60. Coles, G.C.; Bauer, C.; Borgsteede, F.H.M.; Geerts, S.; Klei, T.R.; Taylor, M.A.; Waller, P.J. World Association for the Advancement of Veterinary Parasitology (W.A.A.V.P.) methods for the detection of anthelmintic resistance in nematodes of veterinary importance. Vet. Parasitol. 1992, 44, 35-44. [CrossRef]

61. Amarante, A.F.T.; Bricarello, P.A.; Huntley, J.F.; Mazzolin, L.P.; Gomes, J.C. Relationship of abomasal histology and parasitespecific immunoglobulin A with the resistance to Haemonchus contortus infection in three breeds of sheep. Vet. Parasitol. 2005, 128, 99-107. [CrossRef] [PubMed]

62. Schallig, H.; Van Leeuwen, M.; Hendrikx, W. Immune responses of Texel sheep to excretory/secretory products of adult Haemonchus contortus. Parasitology 1994, 108, 351-357. [CrossRef] [PubMed] 